\title{
Factors affecting on bank's profitability: the case of 19 Euro-Area countries
}

\author{
Nexhat KRYEZIU ${ }^{1}$; Egzon HOXHA $^{2}$
}

1) Business and Management Economics, University College UBT - Kosovo

2) Faculty of Economics, University of Prishtina - Kosovo

*To whom correspondence should be addressed. Email: nexhat.kryeziu@ubt-uni.net

\begin{tabular}{|l|l|l|l|l|}
\hline DOI: & Received: & Revised: & Accepted: & Published: \\
10.22437/ppd.v9i1.12165 & 23.02 .2021 & 03.03 .2021 & 11.03 .2021 & 30.04 .2021 \\
\hline
\end{tabular}

\begin{abstract}
The paper has addressed as the main objective the assessment of productivity performance in euro-area nations, observing a combination of factors both in terms of the internal environment and external factors, or known as macroeconomic factors. The analysis includes 19 euro-area countries with 323 observations, including the period 2003-2019. The dynamic approach, the fixed-effect model, and the Arellano / Bond estimator were applied using the panel data to evaluate the study's factors. The analysis shows that the factors under the competence of their internal supervision impact the degree of profitability on the one hand. Macroeconomic factors also show an impact on the degree of profitability for euro-area countries. Five of the seven factors applied in the analysis turned out to significantly impact, while two turned out to be nonsignificant. For further studies, it would be beneficial to apply other dynamic models by using other specific factors, which will be considered a useful input to the financial industry and financial policy-making.
\end{abstract}

Keywords: Fixed-effect, GMM, Panel data, Profitability

JEL Classification: G21, G23, G33.

\section{INTRODUCTION}

The area of banking economics, namely the banking system in the current environment of globalization, continues to be a very attractive and challenging area for many studies, researchers, and policymakers. The year 2021 would be a year where many researchers are researching the impact of the global pandemic known as COVID19 on the economy, respectively, on the financial system's productivity and policies towards maintaining financial stability. To conduct such research, many researchers have used various features to conduct their analyses and examine the effects on the banking system's profitability.

Another specificity presented by the researchers is that in their analysis, they have made the application of specific factors of the financial industry and macroeconomic factors by analyzing individual countries and panel countries. Current researchers often used they have applied specific financial industry factors and macroeconomic factors by analyzing individual countries. In contrast, this study examines panel data for 19 countries that are part of the euro area. The non-inclusion of the rest of the euro-area 
countries lies in the fact that data for these countries were not available in the World Bank database. The data used are in the World Bank format, and they are also aggregated for each country separately. Economic activities in each euro area country are considered to impact the profitability of the banking sector directly. Before the outbreak of the Covid-19 pandemic within the individual euro area countries, there was financial instability, despite the austerity measures and directives of the European Central Bank - ECB, which has set strict financial measures supervision after the last global financial crisis.

The motivation to conduct this investigation is to understand which factors impact profitability, considering those issues in bank management and the impact of the problems that are not within the bank's supervisory competence. The dynamic approach was applied, modeling the fixed-effect regression model and the well-known ArellanoBond Estimator method to observe these factors' correlation. This research structure consists of sections starting from the literature review, methodology, and data, econometric analysis, conclusions as a final part.

\section{LITERATURE REVIEW}

Capital adequacy (CAR), likewise recognized as capital to risk-weighted assets, as a proportion, measures a financial strength of a bank by using its capital and assets. From the regulatory point of view, CAR is considered a tool to defend depositors and stimulate financial systems' stability and effectiveness worldwide (Pasiouras \& Kosmidou., 2007). Moreover, Sharif (2015), on his revision by considering the latest seven (7) years data with the time series of the period from 2008 to 2014 through establishing OLS regression models for 13 private commercials in banks of Bangladesh, come to the outcome that that CAR is considerably associated with profitability. Moreover, as Oyetayo et al. (2019) stated, there is a significant association between CAR and banks' productivity in Nigeria. Furthermore, the same author concluded that CAR proves to be a strong factor in profit planning and capital structure decisions.

Whereas when it comes to liquidity and its impact on profitability, Lukorito et al. (2014) used a multiple regression model to analyze bank productivity variation between commercial banks by changing liquidity. They assumed that liquidity is significantly associated with a bank's productivity. Nevertheless, when liquid assets are held entirely, they yield low or zero interest. The revision noted that banks' liquidity was one of the major determinants of Kenyan bank's profitability. Liquidity has a very significant effect on profitability, and however, when liquid assets are held in banks, they generate little or no interest.

Furthermore, there is an opportunity cost when holding low return assets, which eventually outweighs the benefit of any increase in the bank's liquidity resiliency as perceived by funding markets, Durguti, (2020). Banks should maintain adequate liquidity levels through short-term marketable securities to realize profits for the banks (Lukorito et al., 2014). Also, Garcia-Herrero et al. (2009) examined the contributing factor that distresses the efficiency of 87 banks in China for 1997-2004. Their outcomes exposed that CAR, total deposits -to-total assets, interest rates (IR) as well as inflation take a confident impact on banks' efficiency

When it comes to Non-Performing Loans (NPL) affect the bank's profitability, there are various studies made by different authors that have concluded that there is a relationship between NPL and banks' profitability. According to an investigation performed by Eyup et al. (2017), by using a panel regression method, including 1809 observation for 55 Banks in Turkey for a period from 2005 to 2016, they concluded 
there is a noteworthy, adverse relationship among non-performing loans and bank profitability which Return measures on Equity and Return on Asset.

Regarding GDP growth and its effect on banks' profitability, Tan (2012) showing that higher GDP growth leads to lower bank profitability in China. They also found that the Chinese banking industry's profitability is significantly affected by non-performing loans, and Chinese banks with higher levels of capital have lower profitability. Khrawish (2011) revised Jordanian commercial banks for the period from 2000 to 2010 and concluded that inflation has a negative impact on profitability. According to Jeevitha et al. (2019), the inflation rate does not affect the bank's profitability because other major factors like GDP, interest rates, investments, and internal bank variables may affect banks' profitability. On the same revision, there is no important association between inflation and banks' profitability for the period from 2014 to 2018 .

The (HHI) is a monetary measure that evaluates a business's size compared to the level of competition concerning businesses in a similar branch. A small awareness of this indicator reveals that the corporate operates within the closest competition situation (Linares-Mustarós, Coenders, \& Vives-Mestres, 2018).

\section{METHODS}

To investigate the impact of determinants on the banking industry's profitability as a dependent variable, we used other independent variables such as capital adequacy, liquid assets, funds source, asset quality, Herfindahl Hirschman Index, GDP growth, and inflation rate. The study includes data for 19 euro area countries annually, including the period 2003-2019 with 323 observations. The data used in this study are provided from the World Bank database. The methodology used in this study is the dynamic approach through fixed-effect regression and the Arellano-Bond GMM estimator.

We are based on studies conducted by Athanasoglou et al. (2008) and Ablertazzi \& Gambacorta (2009) for selected indicators divided into two subgroups. In Table 1, we will present the study's factors and the expected results.

Table 1. Variables and expected sign

\begin{tabular}{llllc}
\hline Variable & & Denominations & Acronyms & Sign \\
\hline $\begin{array}{l}\text { Dependent } \\
\text { variable }\end{array}$ & Profitability & Return on assets & ROA & \\
\hline $\begin{array}{l}\text { Explanatory } \\
\text { variables }\end{array}$ & Bank-specific & Capital Adequacy & CAR & + \\
& factors & Liquid Assets & LA & + \\
& & Funds source & FS & + \\
& & Assets Quality & NPL's & $+/-$ \\
& & Herfindahl Hirschman Index & HHI & $+/-$ \\
\hline Explanatory & Macroeconomics & GDP growth rate & GDP_g & + \\
variables & factors & Inflation rate & Inf_r & $+/-$ \\
\hline
\end{tabular}

Based on the explanation of the factors included in this examination and the defined methodology on the applied econometric investigation, in the following we will present the equations of the fixed-effect and the GMM estimator:

$$
\begin{gathered}
\mathrm{ROA}_{\mathrm{it}}=\alpha+\beta_{1}\left(\mathrm{CA}_{i t}\right)+\beta_{2}\left(\mathrm{LA}_{i t}\right)+\beta_{3}\left(\mathrm{FS}_{i t}\right)+\beta_{4}\left(\mathrm{AQ}_{i t}\right)+\beta_{5}\left(\mathrm{HHI}_{i t}\right)+\beta_{6}\left(\mathrm{GDP}_{-} \mathrm{G}_{i t}\right) \\
+\beta_{7}\left(\mathrm{IR}_{i t}\right)+\varepsilon_{i \mathrm{it}}
\end{gathered}
$$

The formula according to the dynamic-GMM approach, applying the factors outlined within the $1^{\text {st }}$ difference is: 


$$
\begin{aligned}
& \Delta \mathrm{ROA}_{\mathrm{it}}=\alpha+\mu(\mathrm{ROA})_{\mathrm{t}-1}+\alpha+\beta_{1}\left(\mathrm{CA}_{\mathrm{it}}\right)+\beta_{2}\left(\mathrm{LA}_{\mathrm{it}}\right)+\beta_{3}\left(\mathrm{FS}_{\mathrm{it}}\right)+\beta_{4}\left(\mathrm{AQ}_{\mathrm{it}}\right)+\beta_{5}\left(\mathrm{HHI}_{\mathrm{it}}\right) \\
& +\beta_{6}\left(\mathrm{GDP}_{\mathrm{it}}\right)+\beta_{7}\left(\mathrm{IR}_{\mathrm{it}}\right)+\varepsilon_{\mathrm{it}}
\end{aligned}
$$

\section{RESULTS AND DISCUSSION}

Descriptive statistics, correlation analysis, and some of the important tests on heteroscedasticity and multicollinearity will be presented before applying the dynamic and GMM methods. Based on the information shown in Figure 1, the factors selected for econometric investigation. Figure 2 will give the variations of features by separating them into two groups, explicitly assessing the bank's proficiency and the features influencing the bank's productivity.

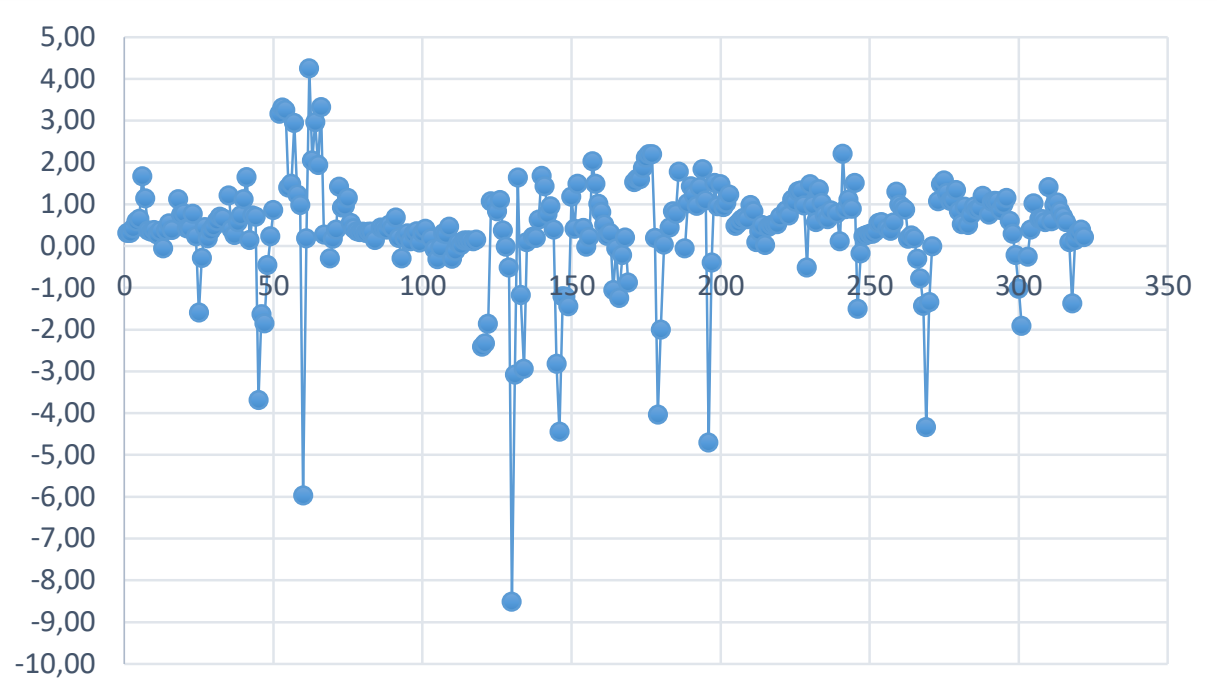

Source: World Banka Dataset \& Author's calculation

Figure 1. Return on assets variation

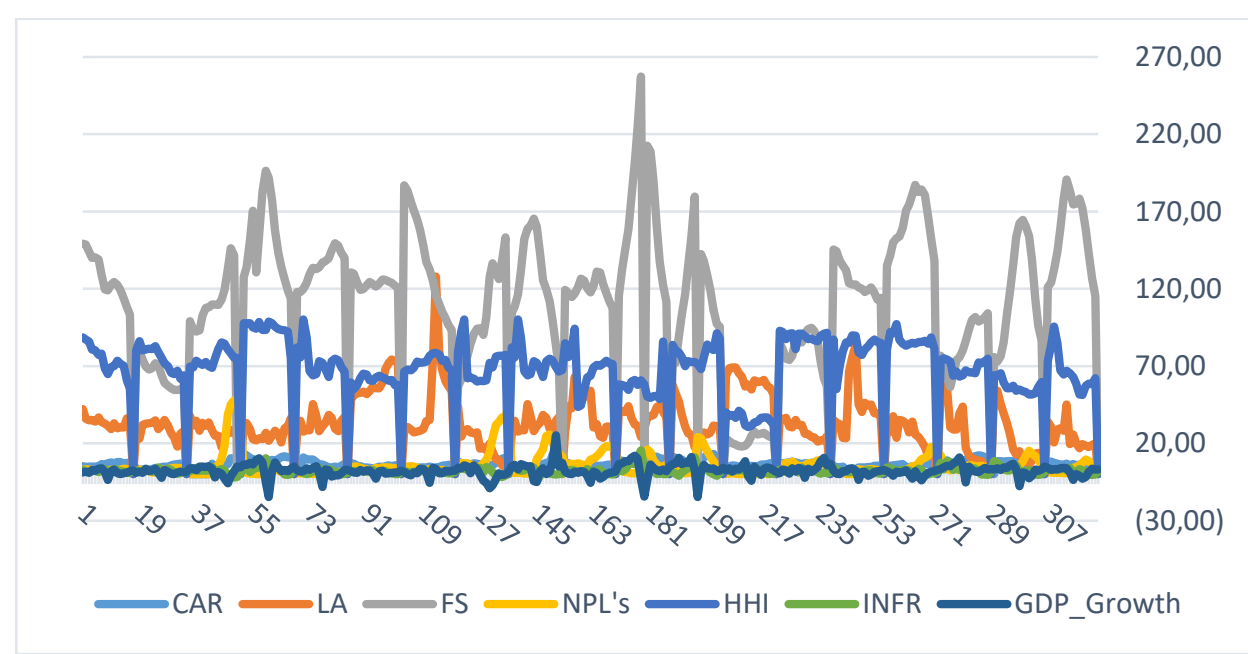

Source: World Banka Dataset \& Author's calculation

Figure 2. Other variables - explanatory factors

Table 2 presents the detailed core statistics for all selected parameters on assessing the degree of profitability. 
Table 2. Summary statistics

\begin{tabular}{lrrrrr}
\hline Variables & Obs & Mean & Std.Dev. & Min & Max \\
\hline ROA & 323 & .37 & 1.24 & -8.52 & 4.24 \\
CA & 323 & 6.66 & 2.72 & 2.70 & 14.35 \\
LA & 323 & 32.43 & 17.46 & 5.27 & 127.97 \\
FS & 323 & 109.49 & 49.45 & 17.97 & 257.32 \\
AQ & 323 & 5.91 & 7.89 & .01 & 48.68 \\
HHI & 323 & 67.47 & 21.85 & 30.61 & 100.00 \\
GDP_G & 323 & 2.15 & 2.05 & -14.81 & 25.12 \\
IR & 323 & 2.19 & 3.88 & -4.48 & 15.40 \\
\hline
\end{tabular}

The return on assets shows the mean constant among periods was with a coefficient of .37 and a standard deviation of 1.24 . The minimum value has reached 8.52, this value achieved by Greece in 2011, while the maximum has reached 4.24 value achieved by Estonia in 2011. Capital to assets have variations with a standard deviation of 2.72. The minimum value is 2.70, reached in 2001 in Belgium's banking system, while the maximum value is 14.35 was reached in Ireland's banking system in 2017. The liquid assets measurement indicator reached a minimum value in 2016, in Greece, with a value of 2.70 , while the maximum value of 127.97 was reached in Germany's banking system in 2011. The parameter that has to do with the financing fund sources is noticed that there are oscillations within the euro-area countries with a standard deviation of 49.45. This indicator's minimum value is 17.97 achieved by Luxembourg in 2006, and the maximum was 257.32 in the Latvian banking system in 2008.

Asset quality is the main indicator that can destabilize the financial system within a country. Regulatory authorities have committed great importance to maintain financial stability. This indicator reached the minimum value in Luxembourg's banking system in 2006 at only 0.10 , while the maximum reached 48.68 in 2014 in Latvia's banking system.

Regarding the degree of market concentration or market share, the HHI indicator reached a minimum value of 30.61 in the Luxembourg banking system in 2006. Finland reached a maximum value of 100 in 2003 . The next variable that is considered an external factor on the measurement of banks' profitability is GDP_growth. The minimum value is -14.81 , while the maximum is 25.12 achieved by Lithuania in 2009 respectively by Ireland in 2015. And at the bottom is inflation, where the minimum value achieved is -4.48 reached in 2009 in Ireland and the maximum is 15.40 achieved in 2008 by Latvia.

Table 3 indicates the correlations among the variables applied to return on assets, which is the main indicator for measuring profitability. It is noticed that the return on assets has a significant association with a coefficient of 0.545 or 54.5 percent. In comparison, a strong negative association has the return on assets with the quality of assets or non-performing loans with a constant of -0.355 or 35.5 percent. However, other variables show a moderate positive relationship with the return on assets.

Table 3. Correlation statistics

\begin{tabular}{lcrrrrrrr}
\hline Variables & ROA & \multicolumn{1}{c}{ CA } & \multicolumn{1}{c}{ LA } & \multicolumn{1}{c}{ FS } & AQ & HHI & GDP_G & IR \\
\hline ROA & 1.000 & & & & & & & \\
CA & 0.167 & 1.000 & & & & & & \\
LA & 0.136 & -0.229 & 1.000 & & & & & \\
FS & 0.031 & -0.071 & 0.047 & 1.000 & & & & \\
AQ & -0.355 & 0.248 & -0.283 & -0.024 & 1.000 & & & \\
HHI & 0.090 & 0.004 & 0.183 & 0.538 & -0.025 & 1.000 & & \\
GDP_G & 0.188 & -0.041 & 0.045 & 0.139 & -0.311 & 0.044 & 1.000 & \\
IR & 0.545 & 0.235 & 0.068 & -0.122 & -0.205 & -0.026 & 0.153 & 1.000 \\
\hline
\end{tabular}


Based on the outputs generated in this study, it would initially be necessary to analyze and discuss some applied tests that determine the applied models' importance and adequacy. The F-test has a coefficient of 7.28 , with a probability of 0.000 . It tells us that all the constants applied in the model have a value less than 10. Based on this, we can state that the parameters are suitable for a stable examination. Additional arguments that add value to the model's stability are R-squared is in the value of 0.541 , which means that the explanatory variables impact or describe the dependent variable at the level of 54.1 percent.

At the same time, R-adjusted tells us that there is an association among properties at the level of 37.7 percent. For evaluating the second approach through GMM estimation, we have applied the AR (1) test, where wald chi2 is 173.34 with a probability of 0.000 , which indicates the adequacy of the applied approach. Finally, concerning the applied tests is also the Kao-test for data co-integration. This test's outputs show that the applied data have no co-integration since the test's value is 10.772 with probability $\mathrm{P}=0.000$.

Table 4. Estimation results

\begin{tabular}{|c|c|c|c|c|}
\hline \multirow[t]{3}{*}{ Variable } & \multirow{2}{*}{\multicolumn{2}{|c|}{$\begin{array}{c}\text { Fixed Effects regression } \\
\text { model }\end{array}$}} & \multicolumn{2}{|c|}{ GMM- Arellano-Bond Estimation } \\
\hline & & & $\mathrm{ROA}$ & lag \\
\hline & Coefficient & $\mathrm{P}>[\mathrm{t}]$ & Coefficient & $\mathrm{P}>[\mathrm{t}]$ \\
\hline Constant & -.8426317 & 0.011 & -.9372655 & 0.005 \\
\hline $\mathrm{CA}$ & .0806817 & 0.012 & .0719395 & 0.031 \\
\hline LA & .0055973 & 0.062 & .0059416 & 0.032 \\
\hline FS & .0039163 & 0.042 & .0039260 & 0.048 \\
\hline AQ & -.0355943 & 0.000 & -.025014 & 0.022 \\
\hline HHI & -.0013239 & 0.764 & -.0004817 & 0.915 \\
\hline IF & .0146096 & 0.633 & -.0025676 & 0.936 \\
\hline GDP_G & .1531046 & 0.000 & .1462573 & 0.000 \\
\hline Observation & 323 & 323 & 323 & 323 \\
\hline R-squared & 0.5414 & -- & -- & -- \\
\hline Adj. R-squared & 0.3775 & -- & -- & -- \\
\hline F-test & $\mathrm{F}(7,297)$ & Prob $>\mathrm{F} P=0.000$ & -- & -- \\
\hline Wald Chi 2 & -- & -- & Wald $\mathrm{chi}^{2}=173.34$ & $\mathrm{P}>\mathrm{chi}^{2}=0.000$ \\
\hline Kao test for co-integration & -- & -- & DF t-10.7724 & $\mathrm{P}=0.000$ \\
\hline Model & & Regression Model & & lano-Bond GMM \\
\hline
\end{tabular}

Table 4, which presents the econometric analysis outcomes, shows that capital adequacy has a noteworthy positive effect on euro area banks' productivity. Model 1 with a significance level of 99.9 percent and the evaluation of the dynamic method known as Arrellano-Bond has the same level of significance of 99.9 percent. These outputs give us complete confidence to ascertain that banks with adequate capital or meet the criteria set by regulatory authorities affect banks' most productive performance.

These marks are in full accordance with the studies conducted by (Christaria \& Kurnia., 2016) and the study conducted by Durguti (2020) involving 685 eurozone banks covering the period 2012 2019. The outcomes of these revisions show that capital adequacy has a noteworthy positive effect on banks' effectiveness. The parameter on liquidity measurement in both models has a noteworthy effect on the effectiveness of banks. In the fixed-effect regression model, there is a positive effect with a significance level of 95.0 percent. At the same time, according to the dynamic approach, GMM has a significant positive effect with a significance level of 99.9 percent. Also, the results of the second parameter are in full agreement with the revision conducted by Durguti et al. (2020), which analyzed the banks that operate in Kosovo, including the period 2006- 
2019, and the results of this study show that liquidity has a positive impact on bank performance.

The other parameter that is considered vital is the Funds Source, which has a noteworthy positive effect at the significance level of 95.0 percent in both models. The quality of assets, respectively, non-performing loans, are at the center of many authors' discussion. Our analysis has resulted in the expected outcomes where there is a noteworthy negative effect on bank profitability in both assessments with an importance level of 99.9 percent. This study's outcomes are confirmed by the studies of (LinaresMustarós, Coenders, \& Vives-Mestres, 2018). This revision's outcomes argue that the deterioration of asset quality, respectively non-performing loans, forces banks to allocate reserves to cover losses, leading to a decrease in banks' profits. The last parameter that has a noteworthy positive effect on banks' performance is GDP_growth with an importance level of 99.9 percent in both estimates. This study's results are consistent with the outcomes (Christaria \& Kurnia., 2016) where they argue that any increase in GDP affects the increase in banks' profitability. In contrast, two parameters that have shown non-significant outcomes are the Herfindahl index and inflation.

\section{CONCLUSIONS AND RECOMMENDATIONS}

\section{Conclusion}

The study presently includes investigating the main profitability factors for the 19 Eurozone countries, applying the two valuation methods through the dynamic approach to see their effect on euro area banks' profitability. After performing the empirical analysis, we can underline that the generated results are consistent with the expected results. Therefore, CAR, liquidity, fund of source, asset quality, non-performing loans, and economic growth impact the bank's profitability.

Meanwhile, the other two factors Herfindahl-Hirschman Index (HHI) and inflation, have turned out to be insignificant in the bank's profitability. The study results are consistent with previous studies and make the accurate identification of factors that impact bank productivity.

\section{Recommendations}

Banks need to continue to hold liquid assets to comply with regulatory requirements and respond to customer (depository) requirements, especially in crisis times, even though this does not enable banks to make a high degree of profit. Moreover, the banks' decision-making structures, such as the board of directors, CEOs, and other management structures, focus on internal factors that directly impact banks' profitability. When it comes to risk management practices, it is necessary to increase the credit risk management committee's awareness of non-performing loans, as they directly affect profitability. Using advanced techniques on assessing and preventing financial shocks that may occur in future periods, such as pandemic (COVID-19) situations, is recommended.

\section{REFERENCES}

Albertazzi, U., \& Gambacorta, L. (2009).Bank profitability and the business cycle. Journal of Financial Stability, 5(4), 393-409. http://dx.doi.org/10.1016/j.jfs.2008.10.002.

Athanasoglou, P.P., Brissimis, S.N., \& Delis, M. (2008).Bank specific, industry specific and macroeconomic determinants of bank profitability. Journal of International Financial Markets, Institutions and Money, 18(2), 121-136. http://dx.doi.org/10.1016/j.intfin.2006.07.001. 
Christaria, F. \& Kurnia, R. (2016). The Impact of financial ratios, operational efficiency and non-performing loan towards commercial bank profitability. Accounting and Finance Review AFR, 1(1), 43-50. https://ssrn.com/abstract=3000205.

Durguti, E. A. (2020). Challenges of Banking Profitability in Eurozone Countries: Analysis of Specific and Macroeconomic Factors. Naše gospodarstvo/Our Economy, 66(4), 1-10. https://doi.org/10.2478/ngoe-2020-0019.

Durguti, E. A. ., Krasniqi, E. H. ., \& Krasniqi, D. . (2020). Assessing the Performance of Factors Affecting the Profitability of the Banking System: Evidence from Kosovo. European Journal of Sustainable Development, 9(2), 304-314. https://doi.org/10.14207/ejsd.2020.v9n2p304.

Eyup, L, Niyazi, T, \& Nurcan, O. (2017). Effect of the Asset Quality on the Bank Profitability. International Journal of Economics and Finance, 9(7), 60-68 https://doi.org/10.5539/ijef.v9n7p60.

García-Herrero A, Gavilá, S, \& Santabárbara D. (2009). What explains the low profitability of Chinese banks?. Journal of Banking \& Finance 33(11), 20802092. https://doi.org/10.1016/j.jbankfin.2009.05.005.

Jeevitha, R, Mathew, B, \& Shradha, K. (2019). Impact of Inflation on Bank's Profitability - A Study on Select Banks Profitability. Journal of Emerging Technologies and Innovative Research. 6(6), 38-44.

Khrawish, H.A. (2011). Determinants of Commercial Banks Performance: Evidence from Jordan. International Research Journal of Finance and Economics, 5(5), 1945.

Linares-Mustarós, S., Coenders, G. \& Vives-Mestres, M. (2018). Financial performance and distress profiles. From classification according to financial ratios to compositional classification. Advances in Accounting, 40, 1-10. https://doi.org/10.1016/j.adiac.2017.10.003.

Linares-Mustarós, S., Coenders, G. \& Vives-Mestres, M. (2018). Financial performance and distress profiles. From classification according to financial ratios to compositional classification. Advances in Accounting, 40, 1-10. https://doi.org/10.1016/j.adiac.2017.10.003.

Oyetayo. OJ, Osinubi, T, \& Amaghionyeodiwe, L (2019). Capital Adequacy and Bank Performance: A Case Study of Selected Banks in Nigeria. International Journal of Economics, Commerce and Management, VII(9), 63-78.

Pasiouras, F., \& Kosmidou, K., 2007. Factors influencing the profitability of domestic and foreign commercial banks in the European Union. Res. Int. Business Finance 21 (2), 222-237. https://doi.org/10.1016/j.ribaf.2006.03.007.

Sarah Nabalayo Lukorito, Willy Muturi, Andrew S. Nyang'au, Dennis Nyamasege. (2014). Assesing the effect of liquidity on profitability of commercial banks in Kenya. 5(19), 145-152.

Sharif, S. (2015). A Study on Capital Adequacy and Its Impact on the Banks' Performance. A Panel Data Analysis. Research paper. Available at: https://www.grin.com/document/365422

Tan, Yong \& Floros, Christos. (2012). Bank profitability and GDP growth in China: A note. Journal of Chinese Economic and Business Studies, 10(3), 267-273. https://doi.org/10.1080/14765284.2012.703541.

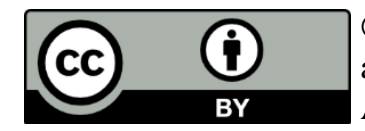

(C) 2021 by the authors. Licensee JPPD, Indonesia. This article is an open-access article distributed under the terms and conditions of the Creative Commons Attribution (CC BY) license (http://creativecommons.org/licenses/by/4.0/). 